\title{
MCM4 wt Allele
}

National Cancer Institute

\section{Source}

National Cancer Institute. MCM4 wt Allele. NCI Thesaurus. Code C52301.

Human MCM4 wild-type allele is located in the vicinity of $8 q 11.2$ and is approximately 17 $\mathrm{kb}$ in length. This allele, which encodes DNA replication licensing factor MCM4 protein, is involved in the modulation of gene replication. 